\title{
Lista czystych przeżuwaczy w Pwt 14,5 w przekładzie Septuaginty
}

\section{The List of Clean Animals in Deut 14:5 in the Septuagint Translation}

\author{
KRZYSZTOF MORTA \\ Uniwersytet Wrocławski \\ krzysztof.morta@uwr.edu.pl, ORCID: 0000-0003-4719-6904
}

Streszczenie: W artykule zostaje poruszona kwestia przekładu w Septuagincie listy zwierząt czystych, dziko żyjących kopytnych przeżuwaczy, zamieszczonej w Pwt 14,5. Zauważalny jest fakt, że tłumacze, podając ekwiwalenty dla hebrajskich nazw roślinożerców występujących w Palestynie, posłużyli się tak egzotycznymi przedstawicielami fauny jak żyrafa. W związku z tym nasuwa się pytanie, czym kierowali się aleksandryjscy tłumacze, wprowadzając do swego przekładu słabo bądź w ogóle nieidentyfikowalne w egipskim środowisku zwierzęta. W artykule podjęto próbę wyjaśnienia tego zamierzenia. Na podstawie przekładu listy czystych przeżuwaczy poruszono także kwestie związane ze starożytną tradycją datacji powstania Septuaginty.

Słowa kluczowe: Septuaginta, Księga Powtórzonego Prawa, zwierzęta, zwierzęta czyste, fauna afrykańska, żyrafa

\begin{abstract}
The article discusses the translation of the clean animals list - wild, undomesticated ruminants - found in the Septuagint, Deut 14:5. It is noticeable that the translators who offered equivalents for the Hebrew names of herbivores inhabiting Palestine made use of such exotic fauna specimens like the giraffe. And that poses a question of what motivated the Alexandrian translators to introduce some animals to their rendition that were barely identifiable - or even entirely unidentifiable - in the Egyptian environment. This paper attempts to explain the ensuing confusion. Based on the translated list of clean ruminants, the article also brings up matters related to the ancient tradition of the dating of the Septuagint.
\end{abstract}

Keywords: Septuagint, Book of Deuteronomy, clean animals, African fauna, giraffe

Dokonany w Aleksandrii przekład ksiąg Starego Testamentu na język grecki przez tzw. Siedemdziesięciu był wyjątkowym i niezwykłym przedsięwzięciem. Pozwolił on uczynić Biblię Hebrajską przystępniejszą i bardziej zrozumiałą nie tylko dla diaspory żydowskiej w Egipcie (i poza nim) ${ }^{1}$, ale też - przez wyjście z hermetyzmu języka hebrajskiego - otworzyć ją potencjalnie dla szerszego greckojęzycznego odbiorcy.

1 Chrostowski, „Sytuacja”, 46-61. Diaspora żydowska stanowiła pokaźną część mieszkańców Aleksandrii. Szacuje się, że w II w. przed Chr. mogła liczyć 100 tys. członków (Stern, „The Period”, 279-281). 
Septuaginta ${ }^{2}$ jest nie tylko pierwszym znanym nam zachowanym starożytnym przekładem Biblii, ale też przekładem szczególnym, bo dokonany z zupełnie innego systemu językowego, jakim kierują się języki semickie, na język indoeuropejski ${ }^{3}$. I chociaż nie możemy rozpatrywać ówczesnego przedsięwzięcia translatorskiego w aspekcie dzisiejszych teorii przekładu biblijnego ${ }^{4}$, to zrozumiałe jest, że tłumacze Septuaginty stanęli przed niełatwym zadaniem zmierzenia się na swój sposób z odmiennością i specyfiką językową hebrajszczyzny; nie tylko z zapisem spółgłoskowym, który utrudniał prawidłowe zrozumienie tekstu, ale z odmiennym systemem fleksyjnym (zupełnie inny sposób pojęcia czasu i jego wyrażania) czy obcą językowi greckiemu składnią. Dochodziły do tego trudności z wieloznaczeniowością słów czy pojęć hebrajskich. Nie zawsze można było znaleźć jedno adekwatne słowo greckie, oddające ściśle ideę czy też dokładne znaczenie odpowiednika hebrajskiego ${ }^{5}$.

Gdy zatem do tych problemów językowych dodamy jeszcze barierę kulturową czy mentalną $a^{6}$ możemy uświadomić sobie, przed jak poważnym wyzwaniem stanęli ówcześni tłumacze, aby z jednej strony uczynić tekst przystępnym i zrozumiałym dla greckojęzycznego odbiorcy, z drugiej - pozostać wiernym oryginałowi.

2 W naszym artykule ograniczamy się do najwęższego znaczenia nazwy Septuaginta, czyli do thumaczenia Pięcioksięgu, części Biblii najwcześniej przełożonej na język grecki, od której zaczęło się całe wielkie translatorskie przedsięwzięcie (zob. Chrostowski, „Gdy Bóg”, 15).

3 Zob. Chrostowski, „Gdy Bóg”, 23: „W świecie greckim i łacińskim istniały dwujęzyczne słowniki, które stanowiły nieocenioną pomoc w przekładach, ale tłumacze żydowskich ksiąg świętych nie mieli żadnych tego typu pomocy. Trudności potęgował fakt, że hebrajski i aramejski z jednej strony, a grecki z drugiej, należą do odmiennych grup językowych. Odzwierciedlają zatem zupełnie inna kulturę i mentalność oraz sposób postrzegania i przeżywania świata".

4 W thumaczeniu Septuaginty obecne są - istniejące w starożytności - dwa podstawowe typy przekładu: dosłowny (używany przy pismach handlowych i prawniczych) oraz swobodny (przy tekstach literackich, narracyjnych). Tak więc podczas gdy Księga Rodzaju, ze względu na swoją treść, odznacza się swobodniejszą translacją, Księga Kapłańska oddaje dokładnie hebrajski oryginał. Zob. Chrostowski, „Gdy Bóg”, 23.

5 Osobną kwestią jest hebrajska etiologia biblijna, oparta głównie na etymologii ludowej. Tłumaczenie tego zjawiska, szczególnie gdy chodziło o pochodzenie nazw własnych, było zadaniem właściwie niewykonalnym dla thumacza (nie sądzimy, aby aleksandryjscy thumacze nie dostrzegli tej rozpowszechnionej, zwłaszcza w Torze, tendencji etymologizowania). Gdy np. Adam (Rdz 2,23) mówi o ulepionej z jego żebra kobiecie, że będzie się nazywać (zacytujmy w tym miejscu za Biblią Poznańską) „mężową, ponieważ z męża jest wzięta”, w tekście hebrajskim to podobieństwo brzmienia i zapisu jest widoczne: לזאת יקרא אשה כי מאיש לקחה זאת - W wersji greckiej ten związek jednak zostaje

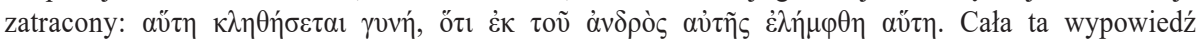
w przekładzie LXX traci sens. Na marginesie dodajmy, że św. Hieronim w swym tłumaczeniu Starego Testamentu z języka hebrajskiego zrobił wszystko, aby ten związek między nazwą kobiety i mężczyzny oddać, i wprowadził dość specyficzną formę virago (notabene określenie, które Rzymianie stosowali dla kobiety parającej się męskimi zajęciami): haec vocabitur virago quoniam de viro sumpta est.

6 Jednym z transparentnych przykładów może być tłumaczenie wyrazu oznaczającego kolczyk Rebeki (Rdz 24,22.24.30.47). Hebrajski tekst mówi o jednym kolczyku, jako ozdobie nosa. Aby nie razić hellenistycznego odbiorcy, w Septuagincie użyto liczby mnogiej, jakby to były kolczyki do uszu. Pominięto też, z tych właśnie względów, fragment mówiący expressis verbis o zawieszeniu kolczyka na nosie Rebeki (Rdz 24,47). Szerzej na ten temat: Harl, La Bible, 203. 
Zrodził się w ten sposób przekład, który powstawał w zupełnie innych warunkach geograficzno-polityczno-kulturowych i na innym etapie wciąż rozwijającego się judaizmu ${ }^{7}$; przekład, który spowodował nie tylko otwarcie się semickiego świata na świat hellenistyczny, ale także przedostanie się do samej Biblii różnych elementów kulturowych i cywilizacyjnych spoza świata semickiego ${ }^{8}$. To przeniesienie za sprawą greckiego przekładu hebrajskich ksiąg Starego Testamentu w świat hellenistyczny, z jego kodami kulturowymi i cywilizacyjnymi, systemami filozoficznymi, pojmowaniem i odbiorem otaczającego świata, w pewnym stopniu odcisnęło też swoje piętno na rozumieniu i interpretacji przekazu biblijnego.

Jednym z podstawowych celów autorów Septuaginty było uczynienie treści tekstu biblijnego zrozumiałym dla tej części diaspory żydowskiej w Egipcie, dla której język hebrajski przestał być zrozumiały. Tłumacze nie tylko starali się przełożyć tekst hebrajski, ale uczynić go bardziej przystępnym przez odpowiedni dobór pojęć, idiomów i ekwiwalentów z kultury hellenistycznej dla realiów biblijnych ${ }^{9}$. Tego rodzaju praktyka czasem powodowała dalsze konsekwencje w postaci uruchomienia szeregu skojarzeń i symboli, związanych z grecką ekwiwalencją. Jak pisze Michał Wojciechowski „Np. jeśli się już przełożyło Szeol jako Hades, trudno było uniknąć skojarzeń greckich i wyrażeń związanych z Hadesem"10.

W przekładzie aleksandryjskich tłumaczy możemy jednak zauważyć także pewne tendencje. Przekład ten bowiem nie powstawał w izolacji od otaczającego go świata, ale w konkretnym czasie i środowisku. Tłumacze Septuaginty uwzględnili zatem warunki panujące ówcześnie w Egipcie, co wpłynęło na to, że znalazły się

7 Dokonana zostaje rewizja i weryfikacja pojęć teologicznych i religijnych. „Grzech” zostaje określony jako àvopía „bezprawie” (Chrostowski, „Gdy Bóg”, 23). Określenie Boga w hebrajskim oryginale

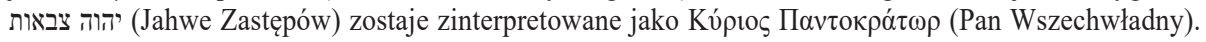
Hebrajski Bóg-wojownik (Wj 15,3): יהוה איש מלחמה (Jahwe mąż wojny) staje się w LXX Kúptos

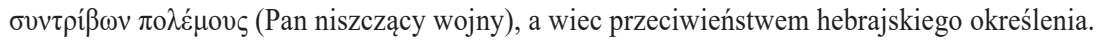

8 „Grecka wersja biblijnych ksiąg świętych sprzyjała usankcjonowaniu greki w środowiskach żydowskich, a tym samym większemu otwarciu na wpływy hellenizmu i filozofii greckiej” (Chrostowski, „Gdy Bóg”, 21).

9 Skutkowało to również wprowadzeniem różnego rodzaju anachronizmów, np. przez odwołanie się w przekładzie do późniejszego systemu monetarnego Greków (dwudrachma zamiast sykl [szekel] [Rdz 20,14]; drachma [Rdz 24,22]; obol [Wj 30,13]); anachronizmów historycznych, czego przykładem może być użycie określenia Syryjczycy zamiast hebr. Aramejczyków (Rdz 22,21; 25,20), co wynikało z tego, że w czasach pracy nad LXX obszar w górnej Mezopotamii, zwany dawniej Aramem, określano jako Syria (por. Pwt 26,5). W greckim przekładzie znajdujemy też cały szereg idiomów, np. „nie mlaśnie ozorem” w miejsce hebr. „nie zaszczeka” (Wj 11,7); pojęć o innych konotacjach i skojarzeniach,

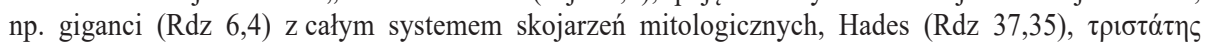
(stojący w trzeci szeregu), które zostało zaczerpnięte zówczesnej sztuki walki w miejsce hebr. doświadczonych weteranów (Wj 14,7). Dokonano też nowych identyfikacji, jak hebr. Morza Sitowia z Morzem Czerwonym (Wj 13,18), i wprowadzono cały szereg ekwiwalentów przy realiach biblijnych, jak choćby w przypadku instrumentów muzycznych, np. tympanon, kitara (Rdz 31,27), strojów, np. chitony (Rdz 3,21; 27,3.32), czy roślin, wprowadzając do Biblii ekwiwalenty występujące w świecie hellenistycznym lub w środowisku egipskim (zob. Geller Nathanson, „,Rośliny”, 689-690) itd.

Wojciechowski, Wplywy, 100. Zob. także Usener, „Griechisches”, 83-89. 
w nim elementy egipskiej rzeczywistości ${ }^{11}$. Przekładając realia biblijne, opierali się na topografii i uwarunkowaniach miejsca, w którym żyli. ${ }^{12}$

Wydaje się jednak, że tłumacze poszli nieco dalej i starali się uwzględnić też preferencje, reakcje, by nie powiedzieć oczekiwania dworu królewskiego. Pokrywałoby się to w pewnym stopniu z legendą o powstaniu Septuaginty, która z historią tego tłumaczenia mocno wiąże Ptolemeusza $\mathrm{II}^{13}$. Analizując ten przekład, można dostrzec tendencję do łagodzenia tekstu hebrajskiego o wymowie antyegipskiej i w ogóle różnych kwestii zapalnych związanych z Egiptem, które w hebrajskim oryginale brzmią o wiele mocniej ${ }^{14}$. Dotyczyło to czasem niewielkich, można powiedzieć, subtelnych zmian, jak w przypadku wprowadzenia Sary na dwór faraona $\left(\right.$ Rdz 12,15) ${ }^{15}$ czy kwestii określenia syna Hagar (Egipcjanki) jako „osioł, dziki człowiek" $(\operatorname{Rdz} 16,12)^{16}$.

Oprócz tych przykładów ogólnie dotyczących Egiptu można spróbować doszukać się wpływów na tłumaczenie związanych bezpośrednio z dworem królewskim, a szczególnie z postacią Ptolemeusza Filadelfa. Mogłoby to sugerować szczególne uwrażliwienie tłumaczy na potencjalną reakcję ze strony spadkobierców tradycji egipskiej, jaką stała się hellenistyczna dynastia Ptolemeuszy, wywodząca swój rodo-

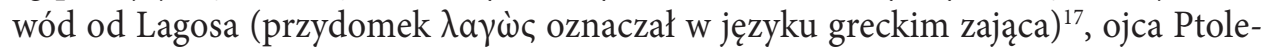
meusza I Sotera. Ten właśnie przydomek mógł spowodować, że wśród zwierząt nieczystych (Kpł 11,6; Pwt 14,7) w greckim przekładzie nie zdecydowano się zamieścić zająca, który byłby naturalnym dobrze rozpoznawalnym ekwiwalentem hebrajskiego zoonimu ארנבת (arnewet) - zając. Zamiast tego tłumacze wprowadzili do tekstu

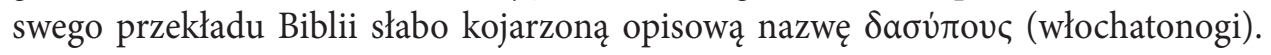

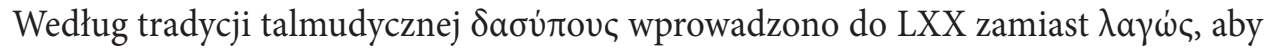
nie drażnić Ptolemeusza Filadelfa, gdyż taki przydomek nosiła jego małżonka. Bardziej prawdopodobne jest jednak, że chodziło o przydomek założyciela dynastii Ptolemeuszy ${ }^{18}$. Ten zabieg translatorski, odnoszący się bezpośrednio do Ptolemeusza II, wskazywałby, że tłumacz brał również pod uwagę uwarunkowania polityczne i reakcję ówcześnie panującego władcy.

Wydaje się, że w tym aspekcie należałoby także widzieć przekład listy dziko żyjących czystych zwierząt parzystokopytnych (Pwt 14,5). A w związku z tym należałoby

11 Koenig, „Quelques”, 223-234; Law, When God, 39-40.

12 Husson, „Le paradis”, 73. Warto tu dla zobrazowania tej kwestii przywołać przykład z księgi Wyjścia $(10,13)$, dotyczący kierunku, skąd nadleciała szarańcza na Egipt. Tekst hebrajski mówi, że przyniósł ją wiatr wschodni (רוח קדים), jak w Palestynie. Tymczasem w LXX tę plagę sprowadza wiatr południowy

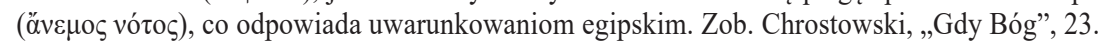

13 Wojciechowski, „List Pseudo-Arysteasza”, 121-167.

14 Kowalik, Reinterpretacja, 393.

15 Kowalik, Reinterpretacja, 394.

16 Kowalik, Reinterpretacja, 394.

17 Stąd członków tej dynastii nazywano także Lagidami.

18 Zob. Wasserstein, „The Ptolemy”, 77-86. 
postawić sobie pytanie, czy nie występuje jakaś zależność między doborem greckich ekwiwalentów hebrajskich zoonimów a zakrojoną na szeroką skalę polityką handlowych i naukowych eksploracji prowadzonych przez Ptolemeusza Filadelfa na południe od Egiptu.

\section{Zwierzęta czyste parzystokopytne Palestyny}

Hebrajski tekst Pwt 14,4-5 podaje listę kopytnych zwierząt czystych, które można spożywać:

זאת הבהמה אשר תאכלו שור שה כשבים ושה עזים איל וצבי ויחמור ואקו ודישון ותאו וזמר

„Oto zwierzęta, które jeść będziecie: wół, owca, koza,

ajjal i cewi i jachmur i akko i diszon i teo i zemer" ${ }^{\prime \prime}$.

Wszystkie te zwierzęta ma łączyć zasada podana w Pwt 14,6, czyli mają przeżuwać i mieć rozdwojone kopyto. Badacze są skłonni widzieć w tej liście najbardziej popularne z dzikich roślinożerców w diecie biblijnych Izraelitów ${ }^{20}$. Zauważono przy okazji, że lista tych zwierząt została ułożona według pewnego klucza, związanego z ich popularnością i występowaniem, czyli od najbardziej rozpowszechnionych do rzadziej goszczących na stołach ${ }^{21}$. Najpierw bowiem pojawia się rogacizna udomowiona (wół, owca, koza), następnie zwierzęta dziko żyjące, ale w kolejności od najczęściej spotykanych i łowionych na polowaniach, jak איל (ajjal) צבי (cewi) Dowodzą tego liczne miejsca w Starym Testamencie, gdzie się o nich wzmiankuje przy różnych okazjach, czy to przy sprawach aprowizacyjnych ${ }^{24}$, czy to przy np. porównaniach ${ }^{25}$. W samej Biblii znajdziemy też pewne, choć nieznaczne, elementy charakterystyki tych zwierząt, wskazujące, że cewi był szybki (2 Sm 2,4), żył w środowisku górskim (1 Krn 12,9; Pnp 2,17; 8,14), miał zgrabną sylwetkę (Pnp 2,9). Podobnie opisywany jest ajjal, jako zwinne i skoczne stworzenie (Iz 35,6). Bardzo często te dwa

19 Nie zdecydowaliśmy się w tym miejscu naszego artykułu na tłumaczenie wszystkich hebrajskich zoonimów ze względu na spory identyfikacyjne i brak w tej kwestii jednoznaczności w nowożytnych przekładach, o czym piszemy niżej. $Z$ tego powodu podajemy hebrajskie nazwy dziko żyjących parzystokopytnych przeżuwaczy w transkrypcji. Tam, gdzie w artykule nie podano źródła tłumaczenia, przekład własny.

20 Majewski, „Zwierzęta czyste”, 382.

21 Zob. Amar - Bouchnick - Bar-Oz, „Contribution”, 11.

22 Wymieniony jest w ST 11 razy.

23 Wymieniony w ST również 11 razy.

$24 \quad 1 \mathrm{Krl} 5,3$.

25 W porównaniach używa się (co zrozumiałe) odniesień do rzeczy znanych i dobrze kojarzonych (Pwt 15,22, Pnp 2,9; 8,14; Ps 42,2). 
zwierzęta są wymieniane razem (Pwt 12,15). Można stąd wnioskować, że występowały one w tym samym środowisku i były bardzo popularne na terenie południowego Lewantu.

Jako trzeci (po ajjal i cewi) na liście zwierząt czystych został wymieniony יחמור (jachmur). Również i ten roślinożerca pojawia się w innym miejscu Starego Testamentu, choć tylko raz. Figuruje jako część królewskiego jadłospisu, który trafiał na stoły Salomona (1 Krl 5,3)5,3):

עשרה בקר בארים ועשרים בקר רעי ומאה צון לבד מאיל וצבי ויחמור וברברים אבוסים

„Dziesięć sztuk bydła karmnego, dwadzieścia sztuk bydła pastewnego, sto owiec, a nadto ajjal, cewi i jachmur i tuczone ptactwo".

Warto zauważyć, że zwierzęta roślinożerne wymienione w tym wersecie są również uporządkowane w kolejności od zwierząt hodowlanych, domowych po dziko żyjące, przy czym ajjal, cewi i jachmur pojawiają się dokładnie w takim porządku jak w Pwt 14,5.

Z wymienionych na liście czystych parzystokopytnych roślinożerców w innym miejscu Biblii odnajdujemy jeszcze jedynie (teo), o którym pojawia się wzmianka u Izajasza $(51,20)$ przy okazji porównania „synów Jerozolimy” do „powalonego teo w sidłach".

Z tych zdawkowych opisów biblijnych, dotyczących tylko części zwierząt czystych, trudno jednak było jednoznacznie wskazać, o jakie gatunki rogacizny chodzi. Można było, badając kontekst, wnioskować tylko bardzo ogólnie, że tak jak teo, który został opisany jako „powalony w sidłach”, może być mniej zwinnym zwierzęciem, mającym większe rozmiary, tak z kolei cewi odznaczał się zwinnością i zrywnością, gdyż służył do porównań dotyczących nieuchwytności, „wyrywania się z ręki” (Prz 6,5).

Podjęto również próby identyfikacji przez analizę etymologiczną zoonimu, np. rzeczony cewi - oznaczający „powab”, „ozdobę”26 - dawał wyobrażenie, że chodzi o smukłe, zgrabne zwierzę pełne polotu, nazwa diszon natomiast (derywat od „bycia tłustym” ${ }^{27}$ wskazywała na zwierzę ociężałe, o masywniejszej budowie. Nie bez znaczenia była też starożytna tradycja identyfikacji (choć w wielu przypadkach myląca lub nieuzasadniona).

Na przestrzeni wieków kolejne tłumaczenia Biblii na języki narodowe oddawały bardzo różnie te hebrajskie zoonimy, używając zazwyczaj pospolitych nazw odbie-

WSHP II, 78.

WSHP I, 210, 222. 
gających od naukowej systematyki ${ }^{28}$. Wystarczy przyjrzeć się polskim tłumaczeniom Pisma św. („w przekładzie z języków oryginalnych”):

- ,jeleń, gazela, daniel, koziorożec, antylopa, bawół i kozica” (Biblia Tysiąclecia, wyd. 5).

- „Jeleń, gazela, daniel, koziorożec, antylopa, dziki wół, dzika koza” (Biblia Poznańska).

- „Jeleń, gazela, daniel, koziorożec, antylopa, oryks, [brak desygnatu dla zemer]” (Księga Powtórzonego Prawa, tł. S. Łach) ${ }^{29}$.

- „Jelenia, sarnę, łanie, koziorożca, bawołu, antylopę i żubra” (Tora, tł. I. Cylkow).

Zrozumiałe jest, że żadne z tłumaczeń nie pretendowało do dokładnej naukowej systematyki zwierząt, nie chcąc czynić z Biblii zoologicznego traktatu, aczkolwiek może należałoby zrezygnować z pewnych mylących nazw. Dotyczy to takich określeń jak dziki wół czy antylopa w kontekście wymienionego po niej oryksa, który przecież też jest antylopą. Jeśli zaś dodać, że gazele należą do podrodziny antylop, chaos w nazewnictwie jeszcze się pogłębi. Przedstawione zatem w tłumaczeniach identyfikacje mają tylko charakter poglądowy i ogólny.

Obecnie naukowcy podejmują jednak próby dokładniejszej identyfikacji tych parzystokopytnych zwierząt czystych, wykorzystując badania interdyscyplinarne, w tym archeozoologię. Powstające nowe stanowiska archeologiczne na terenie dzisiejszego Izraela, ale także innych państw Lewantu, i prowadzone analizy znalezionego tam materiału biologicznego mogą potwierdzić występowanie pewnych gatunków na terenach biblijnych lub je wykluczyć. Daje to większe uprawdopodobnienie podejmowanych prób identyfikacji konkretnych zwierząt. Przy założeniu, że w hebrajskim tekście mamy do czynienia z rogacizną Palestyny, należałoby np. wykluczyć identyfikację zemer z kozicą północną (Rupicapra rupicapra), gdyż ten gatunek nigdy nie żył w południowym Lewancie ${ }^{30}$. W przeszłości bardzo często zresztą podawane były konkretne identyfikacje bez jakiegokolwiek dowodu występowania na terenie Palestyny danego gatunku, np. w przypadku jachmur sugerowano, że może chodzić o gnu brunatne (Conochaetes gnou) $)^{31}$ czy woła domowego (Bubalus bubalis) ${ }^{32}$. Identyfikacje te jednak nie znalazły poparcia w dowodach archeozoologicznych, które by potwierdziły występowania na tym obszarze tych gatunków ${ }^{33}$. Również nie znalazła

28 O różnej ekwiwalencji dzikich zwierząt kopytnych z Pwt 14,5 w staropolskich przekładach zob. Kwilecka, Studia, 108-110.

29 W przypisie (Łach, Księga Powtórzonego Prawa, 184) pojawia się jednak informacja: „Wreszcie zemer określił prawodawca żyrafę, gdyż LXX przełożyła ten wyraz przez kamelopardalis". Jest to jednak wyjaśnienie bardzo mylące, bowiem hebrajski termin nie ma związku z greckim ekwiwalentem, w którym aleksandryjski tłumacz nie szukał dokładnego odpowiednika (o czym piszemy w tym artykule).

30 Amar-Bouchnick - Bar-Oz, „Contribution”, 11.

31 Schwartz, Crops, 364-365.

32 Amar-Serri, „When Did the Water Buffalo”, 63-70.

33 Amar - Bouchnick - Bar-Oz, ,Contribution”, 8. 
potwierdzenia w stanowiskach archeologicznych hipoteza, że zemer to arui grzywiasta (Ammotragus lervia, dawniej nazywana owcą grzywiastą) $)^{34}$.

Powołując się na badania, które przeprowadził zespół naukowców z Izraela ${ }^{35}$, możemy z pewną dozą prawdopodobieństwa dokonać identyfikacji hebrajskich zoonimów z listy zwierząt czystych (Pwt 14,5):

- איל (ajjal) - daniel mezopotamski (Dama mesopotamica) - gatunek z rodziny jeleniowatych (Cervidae), podrodzina jelenie, lub jeleń szlachetny (Cervus elaphus) gatunek z rodziny jeleniowatych (Cervidae).

- צבי (cewi) - gazela górska (Gazella gazella), gatunek z rodziny wołowatych (Bovidae), lub gazela pustynna (Gazella dorcas) - gatunek z rodziny wołowatych (Bovidae).

- יחמור (jachmur) - bawolec krowi (Alcelaphus buselaphus), gatunek z rodziny wolowatych (Bovidae), podrodzina bawolce.

- אקו (akko) - koziorożec nubijski (Capra nubiana), gatunek z rodziny wołowatych (Bovidae), podrodzina koziorożce.

- דישון (diszon) - oryks arabski (Oryx leucoryx), gatunek z rodziny wołowatych (Bovidae), podrodzina antylopowce, rodzaj oryks (na wolności ostatnia sztuka zginęła w 1972 r.).

- תאו (teo) - tur (Bos primigenius), wymarły gatunek z rodziny wołowatych (Bovidae).

- זמר (zemer) ${ }^{36}$ - muflon (Ovis aries musimon), gatunek z rodziny wołowatych (Bovidae), podrodzina koziorożce lub koza bezoarowa (Capra aegagrus), gatunek $\mathrm{z}$ rodziny wołowatych (Bovidae), rodzaj Capra.

Jak zaznaczyliśmy, przedstawione identyfikacje nie są ostatecznym głosem w tej sprawie. Szczególnie dyskusyjne jest odniesienie diszon do oryksa i teo do tura. W przekonaniu innych badaczy można zastosować odwrotne przyporządkowanie. Analizy etymologiczne i odniesienia do innych języków semickich pozwalają bowiem w diszon widzieć tura, a w teo oryksa ${ }^{37}$.

34 Bodenheimer, The Animals, 251.

35 Amar-Bouchnick - Bar-Oz, „Contribution”, 21.

36 Z identyfikacją hebr. zemer jako żyrafą zerwano już w XVII w. po dokładnych badaniach biblijnej ekwiwalencji zwierząt przeprowadzonych przez Samuela Bocharta, który w swym monumentalnym dziele Hierozoicon (902-903) opowiedział się za kozicą górską: „etsi zemer, a plerisque reddatur Camelopardalis, esse potius Capreae genus a saltu sic appellatur". Wywodził bowiem, odwołując się do języka arabskiego, nazwę zemer od czasownika ramaz/zamar - „skakać”, co pasowało mu do charakterystyki przedstawiciela z rodzaju kozic, kozy górskiej (rupicapra). O dziwo, utożsamienie zemer z żyrafą wróciło w ostatnich latach jako hipoteza (Amar - Zivotofsky - Zivotofsky, „The Kashrut”, 491-499). Przypuszczenia (oparte na $1 \mathrm{Krl}$ 10,22), że żyrafa mogła trafić do Izraela i wzbogacić ogrody z egzotycznymi zwierzętami, nie mają żadnej wagi dowodowej w tej kwestii. Próba identyfikacji hebrajskiego zemer jako żyrafy może być postrzegana bardziej w kategoriach naukowej prowokacji i wywołania szerszej dyskusji niż rozwiązania problemu.

37 Keel - Küchler - Uehlinger, Orte, 175, 177. Zob. także Lisowsky, Konkordanz, 1503 (przy identyfikacji z oryksem pojawia się jednak znak zapytania). 


\section{Grecka lista zwierząt czystych parzystokopytnych}

Jeśliby założyć, że przekład na język grecki miał jeden podstawowy cel, tj. uczynić tekst hebrajski zrozumiałym dla greckojęzycznego odbiorcy, autorzy Septuaginty powinni dokonać tego przez zastosowanie odpowiednich ekwiwalentów rozpoznawalnych w świecie hellenistycznym czy też w warunkach egipskich. Może zatem dziwić

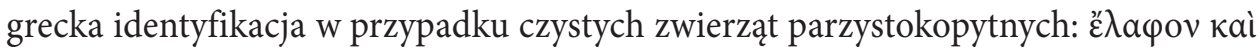

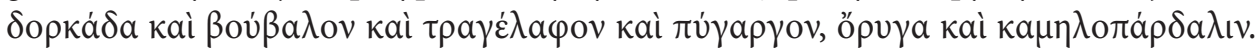
Pojawiają się wśród nich zwierzęta, które w naturalnym środowisku Egiptu nie występowały, i tak egzotyczne, że mogły być tylko okazjonalnie widywane ${ }^{38}$.

Również dla późniejszych starożytnych interpretatorów i egzegetów biblijnych ten zestaw nie do końca był rozpoznawalny i kojarzony. Pojawiające się w nim 3 nazwy złożone (ßoúßa bardziej z mitycznymi hybrydami niż rzeczywistymi przedstawicielami fauny. Stąd też grecki przekład kopytnych roślinożerców wprawił w zakłopotanie tak wybitnego i płodnego komentatora Pisma św. jak Orygenes, który swym w dziele $O z a s a-$

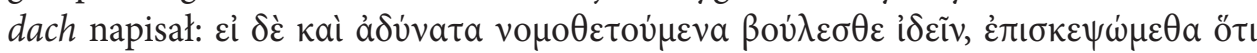

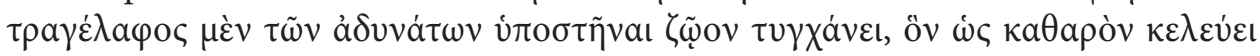

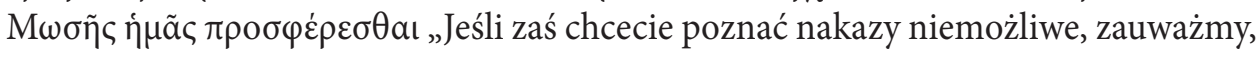
że koziorożec [kozłojeleń - K.M.] jest zwierzęciem, które nie może istnieć, a Mojżesz nakazuje, byśmy podawali go jako czyste zwierzę" ${ }^{\text {"40 }}$. Jak zatem z tego wynika, w oce-

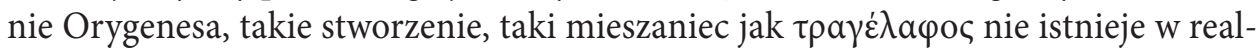
nym świecie ${ }^{41}$ i dlatego aleksandryjski egzegeta rozwiązanie tego problemu widział w egzegezie alegorycznej. Także w późniejszych czasach u teologów tragelafos będzie traktowany na równi z syrenami i hipocentaurami jako mityczne stworzenie ${ }^{42}$.

Jednakże dla autorów Septuaginty, jak wskazuje kontekst, było to stworzenie jak najbardziej realne. W czasach Ptolemeuszy bowiem, kiedy odkrywano wiele gatun-

38 Zwierzyniec LXX mógł opierać się na okazach zgromadzonych w królewskich ogrodach w Aleksandrii, gdzie trzymano dzikie i na pół oswojone zwierzęta (Husson, „Le paradis”, 67).

39 Starożytni widzieli w nich mieszańce łączące ze sobą cechy dwóch różnych rodzajów zwierząt. Zob. Diodorus Siculus, Bibliotheca historica II 51,1.

40 Origenes, De principiis IV,3,2 (Koetschau, 325-326; PSA 23, 314b).

41 W tej kwestii postrzegania tragelafa jako zwierzęcia fantastycznego Orygenes podąża za przekonaniem części starożytnych (zob. Aristophanes, Ranae 937-938, gdzie kozłojelenie pojawiają się w kontekście innych hybryd, jakimi są kurokonie - i $\pi \pi \alpha \lambda \varepsilon \kappa \tau \rho v o ́ v a \varsigma)$. Również w Państwie Platona tragelafy potraktowane są jako wymyślny i skomplikowany wytwór wyobraźni malarza (Plato, Respublica 488a). Podobnie sądziły takie autorytety jak Arystoteles: „Filozof przyrody musi posiadać wiedzę nie tylko o nieskończoności, ale także o miejscu, a mianowicie, czy w ogóle istnieje, czy nie, jaki jest sposób jego istnienia i czym ono jest. Według powszechnego przekonania rzeczy istniejące muszą gdzieś być (to, co nie istnieje, nie znajduje się nigdzie; bo gdzie np. znajduje się kozioł-jeleń albo sfinks?)" (Aristoteles, Physica 208a [Dzieła Wszystkie, 2, 82]).

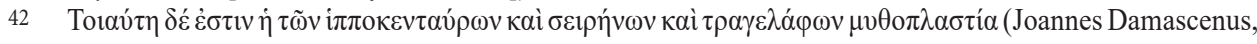
Contra Jacobitas 29,8). 
ków nieznanych dotąd zwierząt, zaczęto wykorzystywać już istniejące lub tworzyć nowe composita, czyli nazwy złożone z dwóch innych nazw bardziej znanych i lepiej kojarzonych stworzeń, których cech dopatrzono się w nowym gatunku ${ }^{43}$. Ponadto trzeba dodać, że w hellenistycznej Aleksandrii wykorzystywano nawet określenia mitycznych stworzeń, jak satyr czy sfinks, aby określić nimi np. różne gatunki nowo odkrytych małp, które były bezspornie realnymi przedstawicielami fauny ${ }^{44}$.

O tragelafie jako realnym zwierzęciu wspominają starożytni autorzy, m.in. Diodor Sycylijski, który bazując na wcześniejszych opisach, wymienia go obok bubalosa wśród rogacizny Arabii ${ }^{45}$, mimo że uważa te stworzenia za swoiste mieszańce ${ }^{46}$ :

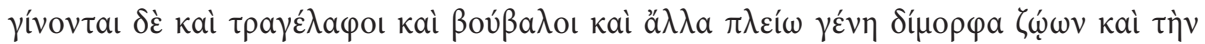

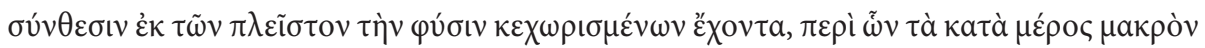

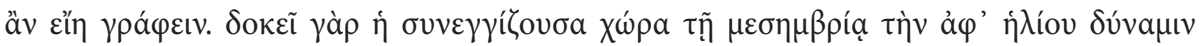

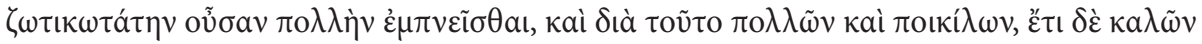

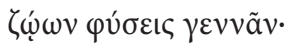

„Żyją tam również kozłojelenie, bawołoantylopy i wiele innych rodzajów zwierząt, które łączą w sobie cechy dwóch, zupełnie różnych zwierząt. Ale o tym długo by można pisać. Wydaje się, że kraina, która leży blisko południowych szerokości, ściąga wiele życiodajnych mocy słońca i dlatego rodzi wiele rozmaitych i pięknych istot żywych" ${ }^{37}$.

Część z parzystokopytnych roślinożerców z listy Septuaginty możemy odnaleźć u Herodota, greckiego podróżnika i dziejopisarza, który opisując faunę afrykańską prawie dwa wieki przed powstaniem Septuaginty, przekazał:

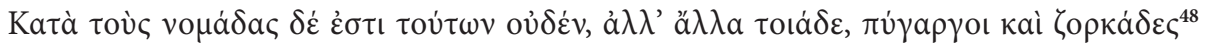

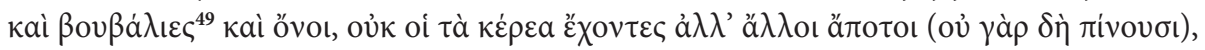

43 „W tego rodzaju złożeniach oba człony nie są równorzędne. [...]. Jeden jest w stosunku nadrzędnym do drugiego. Oznacza to, że w jednej z nazw kryje się główne podobieństwo, a druga użyta nazwa doprecyzowuje opis. Przy czym w tych złożeniach determinatum (określna) jest pierwszym członem, druga nazwa zwierzęcia jest determinantem (określnikiem)” (Morta, „Biblijny szafan”, 358-359).

Zob. Morta, Świat, 91-92. Dzisiejsi uczeni starają się przypisać tym nazwom konkretne gatunki zwierząt. Na przykład sfinksa niektórzy (Woelk, Agatharchides, 178) utożsamiają z koczkodanem Diany (Cercopithecus diana). Zob też Keller, Die antike, 10; McDermott, The Ape, 68. Wiele z tak urobionych czy przystosowanych do nowo odkrytych zwierząt nazw znajdziemy na mozaice z Praeneste (Palestrina). Zob. Meyboom, Nile Mosaic, 20-27.

45 Arabia obejmowała w starożytności terytorium między Morzem Czerwonym a wschodnim brzegiem Nilu; zob. Cancik, Der Neue Pauly, 945-948.

$46 \gamma \varepsilon \dot{\varepsilon} \eta \eta$ Siculus, Bibliotheca historica II 51).

47 Diodorus Siculus, Bibliotheca historica II 51(FHA 34, 83.85).

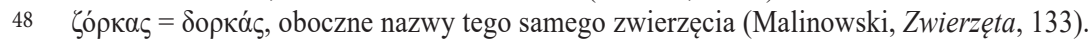

$\beta o v ́ \beta \alpha \lambda ı \varsigma=\beta o v ́ \beta \alpha \lambda o \varsigma$, oboczne formy tego samego zwierzęcia (Malinowski, Zwierzęta, 133). 


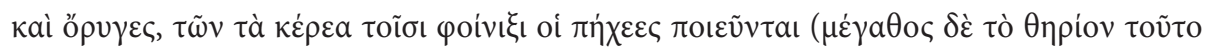

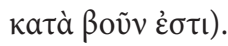

„U koczowników zaś nie ma nic w tym rodzaju, lecz takie są inne zwierzęta: pygargi, gazele, bawoły i osły nierogate, tylko inne, co obchodzą się bez napoju; dalej oryesy [oryksy K.M.], z których rogów sporządza się ramiona do fenickich lir (wielkością dorównuje wołu to zwierzę)" $)^{\prime 5}$.

W relacji Herodota, który pisze o zwierzętach z południa Afryki, pojawiają się

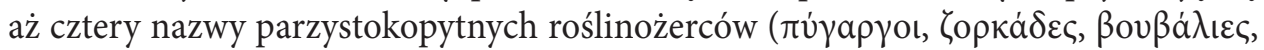

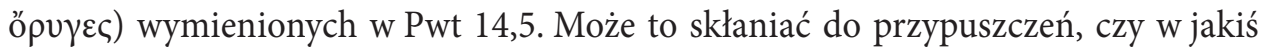
sposób Herodotowy opis fauny afrykańskiej nie wpłynął na tłumaczy aleksandryjskich, tym bardziej że znajomość jego dzieła była w okresie hellenistycznym dość powszechna, i to nawet w kręgach żydowskich ${ }^{51}$. Wydaje się jednak, że tłumacze Septuaginty nie opierali się w tym względzie na literackiej tradycji, ale na własnym doświadczeniu płynącym z obserwacji wydarzeń, które miały miejsce w czasach i miejscu ich translatorskiej działalności. Nie była to jedynie gabinetowa praca nad tekstem oparta na warsztacie teologiczno-filologicznym, ale konfrontacja $z$ otaczającą rzeczywistością i reakcja na bieżące wydarzenia, z odpowiednim ich wykorzystaniem na potrzeby własnego zamysłu translatorskiego ${ }^{52}$. Możemy bowiem zauważyć, że tak jak w przypadku hebrajskiej listy zwierząt czystych panował pewien porządek względem ich popularności (o czym wspomnieliśmy wyżej), tak i w greckiej wersji ten porządek został zachowany. Mimo zupełnie innego klucza doboru ekwiwalentów, tj. rezygnacji z przyporządkowania adekwatnych greckich odpowiedników poszczególnym przedstawicielom hebrajskiej rogacizny, zwierzęta te zostały wymienione w kolejności od najbardziej znanych do rzadko występujących. Po zwierzętach hodowlanych, następnie dziko żyjących, ale powszechnie występujących, jak jeleń i gazela, pojawiają się mniej spotykane gatunki antylop, a listę zamyka najbardziej osobliwe i rzadkie zwierzę, czyli żyrafa. Można powiedzieć, że w przypadku tego właśnie roślinożercy nie ma żadnych wątpliwości co do jego identyfikacji. Było to na tyle egzotyczne i niezwykłe stworzenie, że pojawienie się żyrafy na terenach śródziemnomorskich zawsze wywoływało nie tylko zachwyt, ale skrupulatne odnotowanie tego faktu, czy to w literaturze, czy też w wyobrażeniach plastycznych. Świadczy o tym choćby odpowiednia informacja u Pliniusza Starszego odnośnie do zademonstrowania w roku 46 przed Chr. żyrafy w Rzymie ${ }^{53}$.

\footnotetext{
50 Herodotus, Historiae IV, 192 (Hammer, 343).

51 Murray, „Herodotus”, 200-213; Camponigro, „Judith”, 47-59.

52 Reakcją na przywożone do Aleksandrii nowo odkrytych za Ptolemeusza Filadelfa gatunki zwierząt było wprowadzenie do Septuaginty np. nieznanego nigdzie indziej poza stolicą Ptolemeuszy cherogrilla. Zob. Morta, „Biblijny szafan”, 359-363.

53 Zob. Plinius Secundus, Naturalis historia VIII, 69; Meyboom, Nile Mosaic, 24.
} 
Wprowadzenie więc greckich ekwiwalentów zoonimicznych ze względu na egzotykę kryjących się pod nimi zwierząt nie było podyktowane, jak możemy sądzić, uczynieniem bardziej zrozumiałym i kojarzonym tekstu biblijnego. W takim przypadku użyto by jedynie określeń powszechnie spotykanej w Egipcie rogacizny. Jaki zatem przyświecał tłumaczom cel takiego translatorskiego zabiegu?

Zanim postaramy się odpowiedzieć na to pytanie, należy bliżej przyjrzeć się tej greckiej liście zwierząt czystych. Musimy tu jednak a priori zaznaczyć, że nie jest możliwe dokładne określenie dzikiej rogacizny wymienionej w Septuagincie. Jeśli bowiem założymy, że były to gatunki pokazowe, które trafiły do królewskich zwierzęcych ogrodów ${ }^{54}$, na co wskazuje pojawienie się żyrafy, która w Egipcie nie występowała, możemy tylko ogólnie domniemywać, o jakie okazy chodziło. W takim przypadku dodatkowe badania na polu archeozoologii nie są $\mathrm{w}$ stanie nam pomóc. Na uwagę zasługują za to informacje wcześniejsze, zachowane w pozabiblijnej literaturze greckiej czy łacińskiej. Autorzy starożytni opierając się na różnych opowieściach tubylców, szczególnie myśliwych, pozostawili wzmianki o dziko żyjących roślinożercach $\mathrm{z}$ afrykańskich sawann. Na podstawie analizy tych opisów i relacji dokonanych przez dzisiejszych uczonych zajmujących się antyczną zoologią, możemy tylko w przybliżeniu dokonać próby identyfikacji greckiej listy zwierząt czystych:

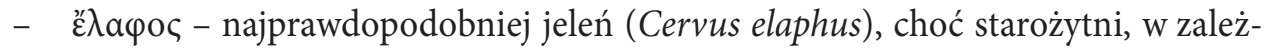
ności od jego występowania, tym mianem określali różnych przedstawicieli rodziny jeleniowatych (Cervidae).

- ठоркás - gazela dorkas. Ogólnie chodzi o drobnych roślinożerców, a w przypadku fauny egzotycznej mogą kryć się pod tą nazwą rozmaite gatunki gazeli. Może zatem być to również gazela arabska (Gazella gazella) ${ }^{55}$. Strabon wymienia ją wśród zwierząt Mauretanii ${ }^{56}$.

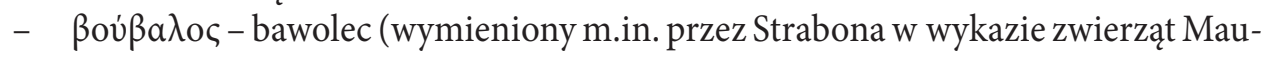
retanii ${ }^{57}$ ). Identyfikowany jest $\mathrm{z}$ bawolcem krowim (Alcephalus buselaphus) ${ }^{58}$. W późniejszych starożytnych opisach zaczął panować chaos identyfikacyjny i pod tą nazwą rozumiano także innych przedstawicieli dziko żyjącej rogacizny, o czym zaświadcza Pliniusz Starszy, pisząc, że dochodziło do pomyłek dwóch różnych rodzajów zwierząt: excellentique vi et velocitate uros, quibus inperitum volgus bubalorum nomen inponit, cum id gignat Africa vituli potius cervique quadam similitudine ${ }^{59}$. „[Germania] rodzi o nadzwyczajnej i sile i prędkości tury, którym nieuczone pospólstwo nadało miano antylop, chociaż ten gatunek zwierząt rodzi Afryka i są one podobne do cieląt i jeleni”.

\footnotetext{
54 Husson, „Le paradis”, 67.

55 Kádár, Some Problems, 52.

56 Malinowski, Zwierzęta, 132.

57 Strabo, Geographica XVII 3,4.

58 Strabo, Geographica XVII 3,4. Zob. także Kitchell, Animals, 18, 140-142.

59 Plinius Secundus, Naturalis historia VIII, 38.
} 


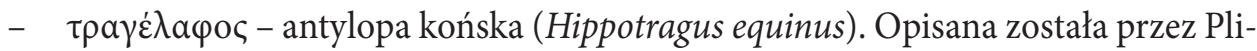
niusza Starszego jako zwierzę podobne do jelenia, ale z charakterystyczną brodą i sierścią na barkach. Pliniusz podaje, że żyje ono nad brzegami rzeki Fasis (obecnie Rion), która wpada do Morza Czarnego: Est eadem specie, barba tantum et armorum villo distans, quem tragelaphon vocant, non alibi quam iuxta Phasim amnem nascens ${ }^{60}$.

- $\pi u ́ \gamma \alpha \rho \gamma o \varsigma$ - gatunek gazeli. Antyczne źródła wymieniają go wśród zwierząt Libii, opisywany też bywa jako płochliwe stworzenie ${ }^{61}$. Część badaczy nie decyduje się na wskazanie konkretnego gatunku ${ }^{62}$. Można jednak spróbować identyfikować tego roślinożercę $\mathrm{z}$ adaksem (Addax nasomaculatus). Zwierzę to nie występowało w okresie historycznym na terenach Lewantu, ale zapewne trafiało wraz $\mathrm{z}$ innymi antylopami do Aleksandrii za sprawą wypraw podejmowanych z inicjatywy Ptolemeusza Filadelfa na południe od Egiptu ${ }^{63}$.

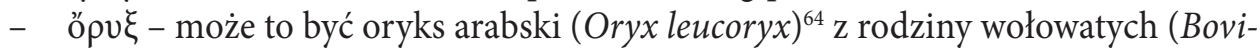
dae), choć niewykluczone, że chodziło o oryksa szablorogiego (Oryx dammah). Na fryzie z grobowca nr 1 z Marissy (Tel Maresha, Izrael) ${ }^{65}$, z czasów pierwszych Ptolemeuszy, zachowały się przedstawienia zwierząt afrykańskich (słoń, nosorożec, żyrafa), wśród których znajdziemy wyobrażenie tego roślinożercy z podpisem OPY $\Xi$. Cechy anatomiczne, m.in. mocniej zakrzywione rogi, odpowiadałyby bardziej temu gatunkowi $z$ rodziny oryks ${ }^{66}$.

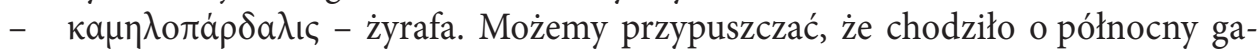
tunek (Giraffa camelopardalis). W dziele Atenajosa Deipnosophistae (Uczta mędrców) przytoczony został opis Kalliksejnosa dotyczący uroczystej procesji ku czci Dionizosa za Ptolemeusza Filadelfa. W opisie tej pompe pojawia się pierwsza wzmianka o żyrafie, która miała kroczyć w orszaku wśród licznych przedstawicieli innych dzikich i egzotycznych zwierząt ${ }^{67}$. Podobnie jak ściągnięty na tę okoliczność nosorożec i biały niedźwiedź (zapewne albinos), była zwierzęciem, które miało zachwycić i wywrzeć wielkie wrażenie na zebranych tłumach ${ }^{68}$.

60 Plinius Secundus, Naturalis historia VIII, 120.

61 Claudius Aelianus, De natura animalium VII, 19; Pliniusz Secundus, Naturalis historia VIII, 79.214.

62 Kitchell, Animals, 156.

63 Amar - Bouchnick - Bar-Oz, „Contribution”, 9.

64 Malinowski, Zwierzęta, 133.

65 Kolonia Sydonu była pod władzą Ptolemeuszy w latach 274-218 przed Chr. Namalowane na północnej ścianie tamtejszego grobowca stworzenie zostało podpisane jako KАMН $\Lambda$ ОАР $\triangle \mathrm{A} \Lambda \mathrm{I} \Sigma$ (dziś napis nieczytelny). Zob. Steinmeyer-Schareika, Das Nilmosaik, 125.

66 Jacobson, The Hellenistic, 30.

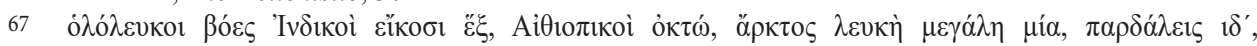

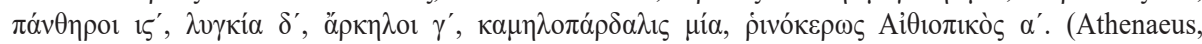
Deipnosophistae V, 32, 35; 201 c). „26 białych wołów indyjskich, 8 etiopskich, 1 wielki biały niedźwiedź, 14 lampartów, 16 gepardów, 4 karakale, 3 serwale, 1 żyrafa, 1 nosorożec etiopski”.

68 Dodajmy, że w opisie dionizyjskiej procesji w Aleksandrii w szeregu egzotycznych zwierząt pojawiają

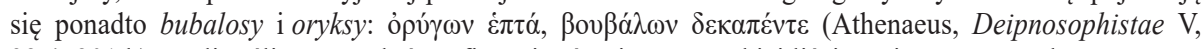
32,4; 201 b), czyli roślinożercy, którzy figurują również na greckiej liście zwierząt czystych. 
Wydaje się całkowicie zrozumiałe, że zwierzę o tak zadziwiającej budowie ciała, zwłaszcza tak długiej szyi, mogło też wywołać dyskusję w samej społeczności Żydów aleksandryjskich co do jego koszerności i kwestii związanych z ubojem rytualnym ${ }^{69}$, a pozytywny rezultat tych przemyśleń znalazł swe odzwierciedlenie w przekładzie.

Wieści o tym niezwykłym zwierzęciu znalazły też oddźwięk w sztuce $\mathrm{z}$ tego okresu. Najwcześniejszy w kulturze hellenistycznej wizerunek żyrafy (III w. przed Chr.) znajdziemy na wspomnianym wyżej fryzie z grobowca z Marissy. Można powiedzieć, że ukazane tam przedstawienie tego zwierzęcia jest nieudolną plastyczną reakcją na niecodzienne wydarzenie, jakim było sprowadzenie przez Ptolemeusza Filadelfa żyrafy do Aleksandrii ${ }^{70}$. Do tych afrykańskich ekspedycji w poszukiwaniu egzotycznych zwierząt nawiązuje także mozaika z Praeneste (Palestrina), która powstała co prawda pod koniec II w. przed Chr. (prawdopodobnie w 108 r. przed Chr.), ale jest kopią o wiele wcześniejszego aleksandryjskiego obrazu sztalugowego ${ }^{71}$. Ukazuje ona bieg Nilu od Delty ku wnętrzu Afryki w okresie wylewu. Przedstawione tam zwierzęta (ok. 40 rodzajów, wśród nich żyrafa) ${ }^{72}$ są plastyczną apoteozą odkryć prowadzonych za Ptolemeuszy, szczególnie Ptolemeusza Filadelfa.

Oprócz przedstawień w sztuce niezwykłych, egzotycznych zwierząt, które trafiały do Aleksandrii za Ptolemeusza II, mamy również odnotowane w literaturze starożytnej informacje o tej polityce hellenistycznego władcy Egiptu. Diodor Sycylijski wzmiankuje, czerpiąc swe wiadomości z wcześniejszych źródeł (za Agatarchidesem, autorem z II w. przed Chr.) $)^{73}$, że za Ptolemeusza Filadelfa odkrytych zostało wiele $z$ dotychczas nieznanych dla śródziemnomorskiego świata gatunków afrykańskiej fauny ${ }^{74}$.

Pewne wyobrażenie związane z polowaniami na afrykańskie zwierzęta i ich transportem do miejsc docelowych daje nam zachowana mozaika $z$ willi Piazza Armerina. Znajdujemy tu co prawda sceny przedstawiające pozyskiwanie egzotycznych

69 Zivotofsky - Zivotofsky - Amar, „Giraffe: A Halakhically”, 203-221.

70 O związku przestawień na fryzie z Marissy z wyprawami Ptolemeusza II zob. Steinmeyer-Schareika, Das Nilmosaik, 105-106.

71 Meyboom, Nile Mosaic, 11.

72 Po kształcie plam możemy nawet przypuszczać, że jest to żyrafa nubijska, północny podgatunek żyrafy afrykańskiej. Zob. Vágner, Zwierzęta, 78.

73 Agatarchides z Knidos, Dzieje, 567.

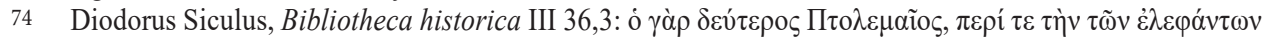

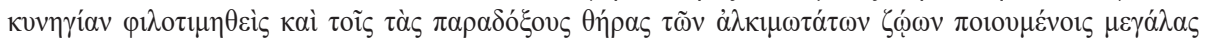

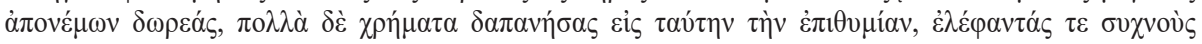

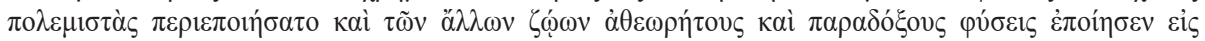

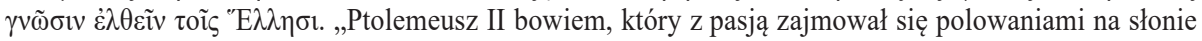
i organizujących niezwykłe łowy na najwaleczniejsze zwierzęta nagradzał sowicie, przeznaczywszy na spełnienie tego pragnienia ogromne fundusze, zgromadził wiele słoni bojowych i sprawił, że niewidziane dotąd i niezwykłe gatunki innych zwierząt zostały poznane przez Hellenów”. Na temat wypraw militarnohandlowo-naukowych za Ptolemeusza Filadelfa na południe Afryki zob. Cary - Warmington, Starożytni odkrywcy, 159-161, 360-361. Szerzej temat traktuje Angela Steinmeyer-Schareika (Das Nilmosaik). 
stworzeń na potrzeby cesarskiego Rzymu, ale przedstawieni tam roślinożercy prawdopodobnie trafiali w ten sposób wcześniej do Aleksandrii. Wyobrażenia są bardzo realistyczne i dobrze oddające anatomię egzotycznej rogacizny ${ }^{75}$. Wśród przedstawionych tam antylop możemy rozpoznać m.in. antylopę końską (ew. antylopowca szablorogiego), oryksa i adaksa.

Wprowadzenie greckiej ekwiwalencji zwierząt roślinożernych różnie jest komentowane. Niektórzy badacze dostrzegają egzotykę tych odpowiedników palestyńskiej fauny i starają się tłumaczyć to chęcią uatrakcyjnienia swego przekładu przez aleksandryjskich tłumaczy. Tak te kwestie widzi np. James K. Aitken, który uważa, że żyrafa nie tylko była egzotycznym stworzeniem, ale w pewien sposób zyskała w Egipcie kulturowe znaczenie ${ }^{76}$. Nie przekonuje natomiast hipoteza Aitkena, że tłumacz Septuaginty kierował się przy zamieszczeniu w swym przekładzie żyrafy również wzglę-

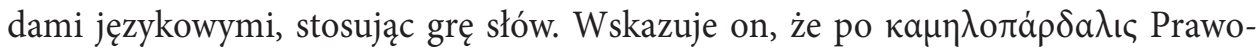
dawca przechodzi do zwierząt nieczystych, wymieniając wielbłąda - ká $\mu \eta \lambda$ os, a więc zwierzę, którego nazwa weszła w skład greckiego compositum określającego żyrafę ${ }^{77}$. Taki zabieg stylistyczny byłby jednak odosobniony w Pentateuchu i trudno przypuszczać, że tłumacz posłużyłby się takim środkiem wyrazu w tekście sensu stricto prawniczym, gdzie nad formą góruje jasny, niedwuznaczny przekaz treści. Inni uczeni upatrują powodów pojawienia się w Biblii tak egzotycznego stworzenia w pomylkach identyfikacyjno-translatorskich. W swej pracy Maja Miziur-Moździoch dopatruje się wprowadzenia żyrafy w Septuagincie w dwuznaczności hieroglifu sr, który w okresie ptolemejskim oznaczał zarówno żyrafę, jak i owcę ${ }^{78}$. Takie rozwiązanie jednak, choć ciekawe i pomysłowe, nie tłumaczy pozostałych egzotycznych ekwiwalencji w greckim przekładzie ${ }^{79}$. Obecność innych egzotycznych zwierząt zaprzecza próbom takiego jednostkowego - oderwanego od całego kontekstu - wyjaśnienia. Kontekst wskazuje bowiem na to, że afrykańska fauna kopytna trafiła do Septuaginty z pewnym translatorskim zamierzeniem, które nie ograniczało się do zwykłego przekładu, ale było gestem tłumaczy wobec odkryć dokonanych przez ekspedycje Ptolemeusza II. Można domniemywać, że przyświecał im cel, aby ich tłumaczenie w ten sposób uwieczniło i uczciło te niezwykłe dokonania.

75 Carandini - Ricci - de Vos, Filosofiana, 220 (fig. 124) - oryks, 211 (fig. 116) - adaks, 216 (fig. 121) bawolec, 200, 204-205 (fig. 108, 111 i 112) - różne rodzaje gazeli i antylop, 184 (fig. 97) - jelenie.

76 „The reason seems to be the cultural prominence that the giraffe gained in Egypt of the third century B.C.E., leading the translator to make the text both Egyptian and exotic [...]. The translator resorts to exoticism in translating the list of animals, possibly reflecting a wider interest in antiquity in fine and peculiar dining” (Aitken, „Why is the Giraffe”, 34).

77 Aitken, „Why is the Giraffe", 34.

78 Miziur-Moździoch, „How a Sheep”, 753-758.

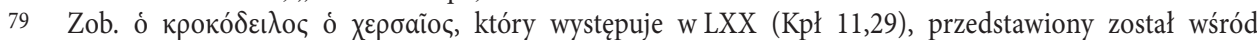
afrykańskiej fauny na mozaice z Palestriny (Meyboom, Nile Mosaic, 26). 


\section{3. Żyrafa a datacja powstania Pięcioksięgu}

Tradycja związana z przekładem na język grecki Tory, czyli Septuaginty w węższym znaczeniu, datowała to przedsięwzięcie na bardzo wczesny okres panowania Ptolemeusza Filadelfa. Tak też odnotował to w swej Kronice Euzebiusz z Cezarei, pisząc przy czwartym roku 124 olimpiady (CXXIV Olympias = lata 284-281 przed Chr.):

Ptolemaeus Philadelphus Judaeos, qui in Aegypto erant, liberos esse permisit: et, vasa Eleazaro Pontifici Jerosolymarum votiva transmittens, divinas Scripturas in Graecam vocem ex Hebraea lingua per LXX Interpretes transferri curavit, quas in Alexandrina bibliotheca habuit, quam sibi ex omni genere litteraturae comparaverat ${ }^{80}$.

Euzebiusz przekazał w tej krótkiej notce informacje znane już z Listu Arysteasza do Filokratesa ${ }^{81}$, wskazując na zaangażowanie w całe przedsięwzięcie Ptolemeusza II, który na początku swego panowania miał postarać się, aby święte księgi Żydów zostały przetłumaczone na język grecki i trafiły do biblioteki aleksandryjskiej.

Podobnie jak Euzebiusz datują przekład Tory na grekę niektórzy uczeni, np. Nina L. Collins ${ }^{82}$. Z drugiej strony większość badaczy przesuwa czas powstania Septuaginty na końcówkę rządów Ptolemeusza II, czyli na połowę III w. przed Chr., przy czym niektórzy, jak Martin Rösel, wskazują nawet dokładny rok powstania przekładu Księgi Rodzaju, czyli 247 przed Chr. ${ }^{83}$

Można więc to podsumować, że w świecie nauki panuje zasadniczo zgoda co do miejsca greckiego przekładu Biblii, którym jest Aleksandria, i co do władcy, którym jest Ptolemeusz II, za którego panowania tego przekładu dokonano. Problem w tym, że Ptolemeusz Filadelf panował długo, bo w latach $285^{84}-246$. Mamy zatem rozpiętość czasową obejmującą prawie cztery dekady.

Wydaje się, że w kwestii czasu powstania greckiego tłumaczenia Tory jakąś wskazówką może być wymieniona na liście czystych zwierząt kopytnych żyrafa. Zamieszczenie w Septuagincie żyrafy, a więc zwierzęcia egzotycznego i wcześniej w Aleksandrii niewidywanego ${ }^{85}$, każe zastanowić się, czy nie ma bezpośredniego związku

80 Eusebius Werke, 129.

81 Wojciechowski, „List Pseudo-Arysteasza”, 121-167.

82 Collins, ,281 BCE. The Year”, 403-503.

83 Rösel, Übersetzung, 66, Rösel, „The Text-Critical”, 63. Badacz ten swoją datacja wiąże z konkretną interpretacją Rdz 2,14 (o rzekach mezopotamskich Tygrysie i Eufracie).

84 Ptolemeusz Filadelf przez pierwsze lata swego panowania (285-283) współrządził ze swym ojcem, Ptolemeuszem Soterem.

85 „Poznanie tego zwierzęcia wiąże się z początkiem ekspansji Ptolemeusza II skierowanej ku Nubii oraz afrykańskim wybrzeżom Morza Czerwonego" (Malinowski, Agatarchides, 593). Żyrafa została wymieniona po raz pierwszy w piśmiennictwie greckim, jak wspomnieliśmy wcześniej, w relacji Kalliksejnosa o pompe. Nie zna jej jeszcze, mimo opisania wielu różnych rodzajów zwierząt, Arystoteles. 
między pojawieniem się tego zwierzęcia w stolicy państwa Ptolemeuszy a pracą tłumaczy w tym mieście.

Wspomnieliśmy wyżej, że tym wydarzeniem, na którym pokazano niezwykłe zwierzęta z żyrafą na czele, była procesja dionizyjska. Fakt, że udało się przywieźć na tę uroczystość do Aleksandrii tylko jedną sztukę, unaocznia nam jeszcze bardziej, jak trudno było złowić to zwierzę i jak niecodzienny i szczególny był to pokaz. Musiał on na obserwujących wywrzeć niezapomniane wrażenie i zafascynować nie tylko uczestniczące w nim tłumy, ale zapewne samych tłumaczy do tego stopnia, że zdecydowali się odnotować to niezwykłe stworzenie w swoim przekładzie Biblii. Zamieszczenie tego zwierzęcia w grupie roślinożerców parzystokopytnych świadczy też, że tłumacze nie byli jedynie przypadkowymi obserwatorami Ptolemejskiej demonstracji niezwykłości świata i natury, ale musieli się temu zwierzęciu dokładniej przyjrzeć i zasięgnąć o nim szczegółowszych informacji ${ }^{86}$.

Tę sytuację i atmosferę, związaną z publicznym zademonstrowaniem żyrafy, w pewnym stopniu może zobrazować nam przywołanie tu starożytnego świadectwa Heliodora, autora Opowieści etiopskiej o Theagenesie i Chariklei, który opisał taką fascynację tłumu tym zwierzęciem:

Znajdowało się wśród nich [niezwykłych darów, które otrzymuje Hydaspes od różnych ludów po zwycięskiej wojnie - K.M.] zwierzę o dziwnym i niespotykanym wyglądzie i dziwnej budowie ciała, wielkością równe wielbłądowi, przypominające kolorem skóry, usianej kolorowymi plamami panterę. [...]. Widok tego zwierzęcia poruszył cały lud i na podstawie najbardziej widocznych cech ciała nazwano je jednomyślnie wielbłądopanterą. Jego pojawienie się wywołało jednak ogólne zamieszanie ${ }^{87}$.

Historia opisana przez Heliodora pochodzi z III lub IV w. po Chr., ale możliwe jest, że charakterystykę żyrafy zaczerpnął z jakiejś wcześniejszej relacji. Możemy tylko wyobrazić sobie, że w ten sam sposób zareagowała społeczność Aleksandrii, i to wtedy zapewne zrodziło się to compositum, złożone z wielbłąda i pantery, powstałe

86 Mimo że żyrafa została wymieniona tylko raz w całej Septuagincie, i to bez jakiejkolwiek charakterystyki, umieszczenie jej w konkretnym zestawie zwierząt czystych oraz zdefiniowanie w Pwt 14,6, o jakie cechy tych zwierząt chodzi, pozwala wnioskować, że tłumacz znał takie szczegóły jej wyglądu, jak to, że ma rozdwojone kopyta i rogi (w rzeczywistości są to tzw. ossikony, przypominające rogi guzy czaszkowe, występujące u osobników obu płci, zob. Estes, The Behavior, 202). Znana też była mu jej natura, czyli

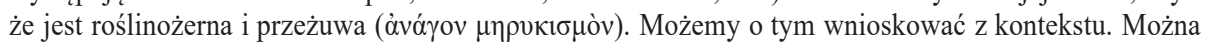
więc powiedzieć, że wiedza żydowskiego tłumacza w Aleksandrii o żyrafie przewyższała pod tym względem informacje starożytnych Greków i Rzymian, którzy (może pod wpływem etymologizowania

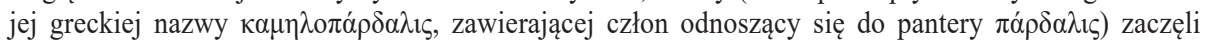
widzieć w niej cechy drapieżnika (Morta, „Did Agatharchides”, 73-74). Wszystko to wskazuje, jak rzadkim zwierzęciem była żyrafa w basenie Morza Śródziemnego i w związku z tym, jak niełatwo było skonfrontować narastające w jej opisach przekłamania z rzeczywistymi faktami. 
na dobrze znanych zasadach doszukania się w nieznanym zwierzęciu cech zwierząt znanych. Takie przypuszczenie wysnuwa przynajmniej część badaczy ${ }^{88}$.

Jeśli zatem uznamy, że tłumacze zetknęli się z żyrafą właśnie podczas pompe, to pojawienie się $\mathrm{w}$ Aleksandrii tego zwierzęcia może być dla nas pewnym wyznacznikiem czasowym. Pozostaje zatem kwestia odpowiedzi na pytanie, kiedy miała miejsce ta manifestacja dokonań Ptolemeusza Filadelfa przy okazji dionizyjskiej procesji? $\mathrm{Na}$ to jednak pytanie nie ma jednoznacznej odpowiedzi. Panuje tu rozpiętość czasowa obejmująca prawie 10 lat ${ }^{89}$. Niektórzy z uczonych opowiadają się za rokiem 279 lub 278. Pojawiła się też propozycja, by wydarzenie przesunąć na lata $270-268^{90}$. Duża część badaczy wskazuje jednak na rok $275^{91}$.

Mimo braku jednoznaczności w datacji pompe możemy, przyjąwszy chronologiczną zasadę przekładu kolejnych ksiąg Tory ${ }^{92}$, gdzie Księga Powtórzonego Prawa powstałaby na końcu całego translatorskiego przedsięwzięcia, datować powstanie Septuaginty na pierwszą dekadę panowania Ptolemeusza Filadelfa.

Fascynacja charakterystycznym wyglądem żyrafy zapewne sprawiła, że alek-

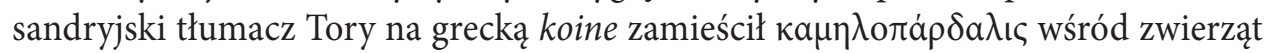
koszernych wymienionych w Księdze Powtórzonego Prawa. Taka reakcja, zawierająca też pewien emocjonalny czynnik, mogła pojawić się w niedługim czasie po owej ptolemejskiej pompe. Oczarowanie i zachwyt niecodziennym widokiem zwierzęcia, które swą wielkością i budową ${ }^{93}$ wyraźnie wyróżniało się spośród innych egzotycznych stworzeń, sprawiły, że tłumacz użył go z pełną świadomością swego wyboru jako ekwiwalentu dla muflona, wymienionego w hebrajskim tekście pod nazwą zemer.

\section{Zakończenie}

Wprowadzenie w Septuagincie fauny z afrykańskich sawann podyktowane było pewnym zamierzeniem. Wszystko wskazuje na to, że tłumacz aleksandryjski w przemyślany sposób odszedł od zastosowania ekwiwalencji oddającej konkretny hebrajski gatunek zwierzęcia przez mniej lub bardziej adekwatny grecki odpowiednik. Przy

„Niezwykle ciekawe jest ostatnie zdanie o nadaniu nazwy zwierzęcia, co może być odległym nawiązaniem do reakcji thumów ptolemejskiej pompe" (Agatarchides z Knidos, Dzieje, 593).

89 Zob. Meyboom, Nile Mosaic, 24.

90 Na temat różnych datowań procesji dionizyjskiej zob. Miziur-Moździoch, „Bestial”, 8. Sama autorka opowiada się za terminem 270-268 przed Chr.

91 Dokładnie kwestie tę przebadała Victoria Foertmeyer („The Dating”, 90-104), wskazując na przełom roku 275/274 przed Chr.

92 Strzałkowska, „Księga Rodzaju”, 95.

93 Starożytni zwracali szczególną uwagę na charakterystyczną asymetryczność budowy jej ciała. Ich zainteresowanie wzbudzała nie tylko nieproporcjonalnie długa szyja żyrafy, ale też dysproporcja między długością kończyn przednich i tylnych. Zob. Malinowski, Zwierzęta, 126-127. 
tłumaczeniu listy czystych zwierząt roślinożernych kierował się on jedynie ogólną zasadą definiującą tę grupę zwierząt jako przeżuwaczy z rozdwojonym kopytem, wprowadził natomiast własną listę przykładów. Dobór odpowiednich zwierząt podyktowany był nie tylko aleksandryjską rzeczywistością, ale i gestem uczynionym w stronę dworu królewskiego.

W przypadku tłumaczenia realiów biblijnych mamy do czynienia z czymś więcej niż przekładem. Jest to przedsięwzięcie wymagające więcej intelektualnego zaangażowania, gdyż należy dokonać odpowiedniego doboru ekwiwalentów z otoczenia, kultury czy wyobrażeń odbiorcy danego języka. Nie jest prostym zadaniem taki dobór ekwiwalentów, aby sens przekładu oddawał sens i wymowę oryginału, nie mówiąc już o całym systemie skojarzeń. W przypadku czystych zwierząt parzystokopytnych autorzy przekładu, jak zaznaczyliśmy wyżej, starali się ułożyć listę greckich odpowiedników zgodnie z hebrajskim porządkiem ich występowania czy popularności. Doboru odpowiednich przedstawicieli zwierząt dokonali już jednak według własnego klucza. Zrezygnowali z powszechnie rozpoznawalnych gatunków parzystokopytnych roślinożerców, żyjących na terenie Egiptu, na rzecz bardziej egzotycznej fauny $z$ afrykańskich sawann, która - jak w przypadku żyrafy - poza Aleksandrią właściwie była nieznana w basenie Morza Śródziemnego. Przykład z grobowca z Marissy, gdzie narysowano żyrafę z dużymi błędami anatomicznymi, dodatkowo dowodzi, jak trudno było o konfrontację z żywym okazem. W samej zaś Aleksandrii żyrafa mogła być widziana okazjonalnie. Ptolemeuszowi II udało się po raz pierwszy (ok. 275 r. przed Chr.) sprowadzić do stolicy swego państwa i pokazać publicznie tylko jedną sztukę tego zwierzęcia.

Dlaczego zatem wprowadzono do Biblii tak egzotyczne i rzadko widywane stworzenie? Nasuwają się dwie odpowiedzi na to pytanie. Pierwsza to zachwyt samych tłumaczy, którzy działali w Aleksandrii, i tam właśnie mogli po raz pierwszy zobaczyć tego najwyższego z żyjących ssaków przy okazji procesji ku czci Dionizosa. Charakterystyczna i niezwykła sylwetka żyrafy zapewne wywołała wśród członków diaspory żydowskiej szerokie dyskusje, choćby związane z jej koszernością. Wydaje się, że autorzy Septuaginty dokładnie przyjrzeli się temu osobliwemu zwierzęciu i poznali jego naturę. Mimo bowiem mylącej nazwy, która zawiera w sobie określenia dwóch zwierząt nieczystych: wielbłąda i pantery, zaliczyli „wielbłądopanterę” do parzystokopytnych przeżuwaczy. Oprócz osobistego zachwytu żyrafą, żydowscy tłumacze prawdopodobnie starali się również, przez wciągnięcie jej na listę zwierząt czystych, uczynić pewien ukłon w stronę władcy Egiptu. Powstający w Aleksandrii za panowania Ptolemeusza II grecki przekład Biblii (według legendy przy dużym nawet zaangażowaniu króla) odzwierciedlał nie tylko stałe elementy egipskiej rzeczywistości, ale - jak widzimy to na przykładzie omawianych zwierząt czystych - reagował na aktualne wydarzenia (gdyby przekład powstał przed odkryciami Ptolemeusza II, grecka ekwiwalencja roślinożerców wyglądałaby zupełnie inaczej). Nie mamy pewności, jak dalece posunięty był to gest w stronę dworu królewskiego i czy przez tę 
egzotyczną listę zwierząt roślinożernych chcieli tłumacze Septuaginty na swój sposób docenić czy też uczcić dokonania Ptolemeusza Filadelfa. Nie ma natomiast wątpliwości, że tym zabiegiem translatorskim skutecznie uwiecznili za sprawą Pisma św. ptolemejskie ekspedycje naukowo-handlowe na południe Afryki ${ }^{94}$.

\section{Bibliografia}

Agatarchides z Knidos, Dzieje (tł. G. Malinowski) (Wrocław: Wydawnictwo Uniwersytetu Wrocławskiego 2007).

Aitken, J.K., „Why Is the Giraffe Kosher? Exoticism in Dietary Laws of the Second Temple Period", Biblische Notizen 164 (2015) 21-34.

Amar, Z. - Bouchnick, R. - Bar-Oz, G., „The Contribution of Archaeozoology to the Identification of the Ritually Clean Ungulates Mentioned in the Hebrew Bible", The Journal of Hebrew Scriptures 10 (2010) 2-24.

Amar, Z. - Serri, Y., „When Did the Water Buffalo Make Its Appearance in Eretz Israel?”, Cathedra 117 (2005) 63-70.

Amar, Z. - Zivotofsky, A.Z. - Zivotofsky, D., „The Kashrut of the Giraffe - a Post-mortem Report", Tehumin 23 (2003) 491-499.

Aristoteles, Physica, tł. pol. K. Leśniak: Arystoteles, Fizyka. O niebie. O powstawaniu i niszczeniu. Meteorologika. O świecie. Metafizyka (Dzieła Wszystkie 2; Warszawa: Wydawnictwo Naukowe PWN 1990).

Ashley, T.R., The Book of Numbers. New International Commentary on the Old Testament (Grand Rapids, MI: Eerdmans 1993).

Bochart, S, Hierozoicon, Sive Bipartitum Opus De Animalibus S. Scripturae: Cujus Pars Prior Libris IV. De Animalibus in Genere, \& de Quadrupedibus Viviparis \& Oviparis: Pars Posterior Libris VI. De Avibus, Serpentibus, Insectis, Aquaticis, \& Fabulosis Animalibus agit. Cum Indice Septuplici... wyd. 4 (Lugduni Batavorum: Boutesteyn \& Luchtmans - Trajecti ad Rhenum: Vande Water 1712).

Bodenheimer, F.S., The Animals of Israel (Tel-Aviv: Devir 1953).

Buquet, T., „Pourquoi la Bible des Septante a-t-elle traduit le zemer du Deutéronome en kamelopardalis ? Réflexions sur le statut symbolique et alimentaire de la giraffe", Anthropozoologica 41/1 (2006) 7-25.

Camponigro, M.S., „Judith, Holding the Tale of Herodotus”, „'No One Spoke Ill of Her.”: Essays on Judith (ed. J.C. VanderKam) (Society of Biblical Literature, Early Judaism and its Its Literature 2; Atlanta, GA: Scholars Press 1992) 47-59.

Cancik, H. (red.), Der Neue Pauly. Enzyklopädie der Antike (Stuttgart - Weimar: Metzler 1996) I.

94 Na marginesie dodajmy, że to tak ważne i charakterystyczne dla greckiego przekładu wprowadzenie żyrafy do tekstu Biblii zostało z jakichś powodów pominięte przez polskojęzyczne tłumaczenie LXX. W dokonanym przez Remigiusza Popowskiego przekładzie w miejscu, gdzie mowa o zwierzętach czystych czytamy bowiem: „Możecie jeść następujące zwierzęta: cielę, jagnię, koźlę, jelenia, gazelę, bawołu, kozicę górską, antylopę, oryksa, koziorożca”. 
Carandini, A. - Ricci, A. - de Vos, M., Filosofiana, the Villa of Piazza Armerina: . The image Image of a Roman aristocrat Aristocrat at the time Time of Constantine (Palermo: Flaccovio 1982).

Cary, M. - Warmington, E.H., Starożytni odkrywcy (tł. B. Wojciechowski) (Warszawa: Państwowe Wydawnictwo Naukowe 1968)

Chrostowski, W., „ «Gdy Bóg przemówił po grecku» Geneza, natura i oddziaływanie Septuaginty", Biblia w przekładach i komentarzach (red. K. Morta) (Wrocław: Uniwersytet Wrocławski. Pracownia Starożytnego Bliskiego Wschodu i Tradycji Biblijnej 2019) 15-29.

Chrostowski, W., „Sytuacja językowa na terenie Palestyny w epoce przedchrześcijańskiej”, Przegląd Powszechny 4 (1984) 46-613; (1985) 329-342.

Collins, N.L., „281 BCE: - the The Year of the Translation of the Pentateuch into Greek under Ptolemy II", Septuagint, Scrolls and Cognate Writings (red. G. J. Brooke - B. Lindars) (SBL Septuagint and Cognate Studies 33; Atlanta, Georgia GA: Scholars Presss 1992) 403-503.

Diodorus Siculus, Bibliotheca historica, tł. pol. M. Wróbel: Diodor Sycylijski, Starożytności asyryjskie i indyjskie (Fontes Historiae Antiquae. Zeszyty Źródłowe do Dziejów Społeczeństw Antycznych 34; Poznań: Wydawnictwo Naukowe UAM 2017).

Estes, R.D., The Behavior Guide to African Mammals. Including Hoofed Mammals, Carnivores, Primates (Berkeley, CA - Los Angeles, CA: University of California Press 1992).

Eusebius Werke. VII. Die Chronik des Hieronymus, Hieronymi Chronicon (red. R. Helm) (Leipzig: Hinrichs'sche Buchhandlung 1913).

Foertmeyer, V., „The Dating of the Pompe of Ptolemy 11 Philadelphus”, Zeitschrift für Alte Geschichte 37/1 (1988) 90-104.

Geller Nathanson, B., „Rośliny”, Słownik wiedzy biblijnej (red. B.M. Metzger - M.D. Coogan; tł. A. Karpowicz et al.) (Warszawa: Vocatio 1996).

Harl, M., , La Bible d'Alexandrie. 1. La Genèse. Traduction du texte grec de la Septante (Paris: Editions du Cerf 1986).

Heliodorus, Aethiopica, tł. pol. S. Dworacki: Opowieść etiopska o Theagenesie i Chariklei (Poznań: Wydawnictwo Naukowe UAM 2000).

Herodotus, Historiae, tł. pol. S. Hammer: Herodot, Dzieje (Warszawa: Czytelnik 1954).

Husson, G., „Le paradis de délices (Genèse 3,23-24)”, Revue des Études Grecques 101 (1988) 64-73.

Isidorus Hispalensis, Etymologiarum sive originum. Libri XX (red. W.M. Lindsay) (Oxonii: e Typographeo Clarendoniano 1911).

Jacobson, D.M., The Hellenistic Paintings at Marisa (Leeds: Maney 2007).

Kádár, Z., „Some Problems Concerning the Scientific Authenticity of Classical Authors on Libyan Fauna, Libyan Animals in the Work of Strabo of Amasea", Acta Classica Universitatis Scientiarum Debreceniensis 24 (1988) 51-56.

Keel, O. - Küchler, M. - Uehlinger, C., Orte und Landschaften der Bibel. I. Graphisch-geschichtliche Landeskunde (Zürich - Einsiedeln - Köln: Vandenhoeck \& Ruprecht 1984).

Keller, O., Die antike Tierwelt (Leipzig: Engelmann 1909).

Kitchell Jr, K.F., Animals in the Ancient World from A to Z (London - New York: Routledge 2014).

Koehler, L. - Baumgartner, W. - Stamm, J.J., Wielki słownik hebrajsko-polski i aramejsko-polski Starego Testamentu (red. P. Dec) (Warszawa: Vocatio 2008) (=WSHP). 


\section{KRZYSZTOF MORTA}

Koenig, Y., „Quelques «égyptianismes» de la Septante”, BIFAO 98 (1998) 223-233.

Kowalik, K.P., Reinterpretacja tekstu o Abrahamie $z$ Rdz 11,27-25,18 w Septuagincie (Series Biblica Paulina 8; Częstochowa: Edycja Świętego Pawła 2010).

Kwilecka, I., Studia nad staropolskimi przekładami Biblii (Poznań: UAM. Wydział Teologiczny - PAN. Instytut Slawistyki 2003).

Laufer, B., The Giraffe in History and Art (Chicago, IL: Field Museum of Natural History 1928).

Law, T., When God Spoke Greek. The Septuagint and the Making of the Christian Bible (Oxford New York: Oxford University Press 2013) 39-40.

Lisowsky, G., Konkordanz zum hebräischen Alten Testament (Stittgart: Deutsche Bibelgesellschaft 1981).

Łach, S., Księga Powtórzonego Prawa (Pismo Święte Starego Testamentu 2/3; Poznań - Warszawa: Pallottinum 1971).

Majewski, M., „Zwierzęta czyste i nieczyste w Starym Testamencie. Część I: Omówienie prawa czystości zwierząt”, Zeszyty Naukowe Stowarzyszenia Biblistów Polskich 11 (2014) 375-398.

Malinowski, G., Zwierzęta świata antycznego. Studia nad „Geografią" Strabona (Wrocław: Wydawnictwo Uniwersytetu Wrocławskiego 2003).

McDermott, W.C., The Ape in Antiquity (Baltimore, MD: Johns Hopkins Press 1938).

Meyboom, P.G.P., The Nile Mosaic of Palestrina. Early Evidence of Egyptian Religion in Italy (Leider - New York - Köln: Brill 1995).

Miziur-Moździoch, M., „Bestial Rivalry: Animals Propaganda in the Hellenistic Kingdoms”, Eos 102/1 (2015) 7-28.

Miziur-Moździoch, M., „How a Sheep Turned into a Giraffe: The Case of Deuteronomy 14:5”, Vetus Testamentum 70/4-5 (2020) 753-758.

Morta, K., „Biblijny szafan - problem identyfikacyjno-egzegetyczny”, Verbum Vitae 32/1 (2017) 351-396.

Morta, K., „Did Agatharchides mention an african name of giraffe?”, Živa Antika 64 (2014) 73-92.

Morta, K., Świat egzotycznych zwierząt u Solinusa (Wrocław: Wydawnictwo Uniwersytetu Wrocławskiego 2004).

Murray, O., „Herodotus and Hellenistic Culture”, The Classical Quarterly 22/2 (1972) 200-213.

Origenes, De principiis, tł. pol. S. Kalinkowski: Orygenes, O zasadach (Pisma Starochrześcijańskich Pisarzy 23; Warszawa: Akademia Teologii Katolickiej 1979).

Origenes, Vier Bücher von den Prinzipien (red. H. Görgemanns - H. Karpp) (Darmstadt: Wissenschaftliche Buchgesellschaft 1976).

Origenes Werke. V. De Principiis (red. P. Koetschau) (Leipzig: Hinrichs'sche Buchhandlung 1913) 325-326.

Pismo Święte Starego i Nowego Testamentu (red. M. Peter - M. Wolniewicz) (Poznań: Księgarnia Św. Wojciecha 1991) (= Biblia Poznańska).

Rambiert-Kwaśniewska, A., Terminologia tekstylna w Biblii Hebrajskiej i Septuagincie. Włókna i tkaniny (Warszawa: Vocatio 2019).

Rösel M., „The Text-Critical Value of Septuagint-Genesis”, Bulletin of the International Organization for Septuagint and Cognate Studies 31 (1998) 62-70. 
Rösel, M., Übersetzung als Vollendung der Auslegung. Studien zur Genesis-Septuaginta (Beihefte zur Zeitschrift für die alttestamentliche Wissenschaft 223; Berlin - New York: De Gruyter 1994).

Schwartz, Y., Crops of the Land of Israel (Jerusalem: Ariel 1900).

Septuaginta, czyli Biblia Starego Testamentu wraz z ksiegami deuterokanonicznymi i apokryfami (przekł. R. Popowski) (Warszawa: Vocatio 2013).

Steinmeyer-Schareika, A., Das Nilmosaik von Palestrina und eine ptolemäische Expedition nach Äthiopien (Bonn: Habelt 1978).

Stern, M., „The Period of the Temple”, A History of the Jewish People (red. H.H. Ben-Sasson et al.) (Cambridge, MA: Harvard University Press 1997) 185-285.

Strabo, Geographica (red. G. Kramer) (Berolini: Nicolai 1844-1852) I-III.

Strzałkowska, B., „Księga Rodzaju w Septuagincie”, Biblica et Patristica Thoruniensia 4 (2011) 95-121.

Tora. Piecioksiąg Mojżeszowy (tł. I. Cylkow) (Kraków: Austeria 2006).

Usener, K., „Griechisches im Griechisch der LXX”, Et sapienter et eloquenter. Studies on Rhetorical and Stylistic Features of the Septuagint (red. E. Bons - T.J. Kraus) (FRLANT 241; Göttingen: Vandenhoeck \& Ruprecht 2011) 3-98.

Vágner, J., Zwierzęta Afryki (tł. R. Oktaba) (Racibórz: R.A.F. Scriba 1996).

Wasserstein, D.J., „The Ptolemy and the Hare: Dating an Old Story about the Translation of the Septuagint", Scripta Classica Israelica 17 (1998) 77-86.

Wild, J.P., „The Eastern Mediterranean, 323 BC-AD 350”, The Cambridge History of Western Textiles (red. D. Jenkins) (Cambridge: Cambridge University Press 2003) I, 102-117.

Woelk, D., Agatharchides von Knidos., Über das Rote Meer (Dys. Universität Freiburg; Bamberg: Universität Freiburg 1966).

Wojciechowski, M., „List Pseudo-Arysteasza”, Studia Theologica Varsaviensia 40/1 (2002) 121-167.

Wojciechowski, M., Wpływy greckie w Biblii (Kraków: WAM 2012).

Wright III, B.G., The Letter of Aristeas: 'Aristeas to Philocrates' Or 'On the Translation of the Law of the Jews' (Berlin - Boston, MA: De Gruyter 2015).

Zivotofsky, D. - Zivotofsky, A.Z. - Amar, Z., „Giraffe: A Halakhically Oriented Dissection”, The Torah uU-Madda Journal 11 (2002-2003) 203-221. 
